\title{
An Analytical-Exploratory Approach to a Socially-Optimal, Sustainable, and Balancing Social Security System
}

\author{
Reza G. Hamzaee, Ph.D. \\ BOG-Distinguished Professor of Economics \\ Department of Economics, Political Science, and Sociology \\ Missouri Western State University \\ 4525 Downs Drive, St. Joseph, M0 64507 \\ Stephanie Michelle Dilley \\ Missouri Western State University \\ 4525 Downs Drive, St. Joseph, MO 64507 \\ Mengmeng Wang \\ Missouri Western State University \\ 4525 Downs Drive, St. Joseph, MO 64507
}

\begin{abstract}
We are indebted to Dr. Murray Nabors, Dean of College of Liberal Arts \& Sciences at Missouri Western State University (MWSU), for his ongoing intellectually stimulating exchange of ideas \& inspiring leadership. Dr. Nabors' support through MWSU Portal Program of Research Teaching \& Applied Learning is also greatly appreciated.
\end{abstract}

"He who learns but does not think, is lost. He who thinks but does not learn is in great danger."

Kong Qiu (Confucius)

\begin{abstract}
While providing its $83^{\text {rd }}$ year of service, our Social Security Administration (SSA) in the U.S. has been the center of strongly justifiable concerns by most financial experts, policymakers, and politicians in this country for more than 2 decades. Several problems are addressed, the most serious one of which has to do with a growing gap between SSA's prospective liabilities and accumulated reserves in just a few years ahead. If that imbalance continues, one of the biggest financial saving sources for many Americans would be dried out, which could add to the list of some major existing challenges that this nation is facing. Other challenges, beyond the context of this research, are healthcare accessibility, growing cost of higher education, and some inadequate retirement programs for many to encounter. This research will provide a critical review of the system, as is, a review of the major innovative policy resolutions, and it finally provides a newly proposed approach to giving the social security fund more dynamic growth and adequacy as well as some project-management-based policy prescriptions for its sustainability. While an explorative analysis is applied, data sources are mainly from Boston College and Social Security Administration.
\end{abstract}

\section{INTRODUCTION}

Social Security benefits, including supplemental income have been some major sources of assistance and funds for millions of Americans. Employees have secured prospective incomes through both their own and their employers' monthly investments. Pension funds, life insurance companies, and most other non-depository institutions have been envies of depository institutions in the sense that they can invest huge reserves into long-term assets with no major 
worries about clients' major withdrawals. This is an advantage that would be most appreciated when funds management is done most professionally and efficiently. Banks' clients' short-term denominated deposits, in contrast, can be claimed any day. So banks cannot enjoy the luxurious liberty in more flexible portfolio management that other non-depository institutions are provided with. Hence, one of the major issues has to do with a growing gap between SSA's prospective liabilities and accumulated reserves in just a few years ahead. If that imbalance continues, one of the biggest financial saving sources for many Americans would be dried out, which could add to a list of some other major existing challenges that this nation is anxiously facing.

\section{THE BACKGROUND REVIEW}

Other problems are analyzed by many authors, one of which involves issues related to demographic changes. Life expectancy has been growing in most countries, including the U.S. This issue is still related to a lack of better planning of funds for such demographic changes. Yet in recent years after the Great Recession (2007- 2009) the U.S. labor force participation rate for the ages of 16 and above has been declining from about 66 percent all the way down to 62.5 percent throughout 2015. In the early 2016, that rate has been stabilized around 63 percent, which is noticeable drop. That has not been any help to a diminishing reserves of the SSA. When fewer people look for work and give up working and contributing to the social security funds, SSA's liability would increase. That is the case since some of their monthly benefits would be provided from SSA funds to bring one of the spouses benefits up to half of what the other higherearning spouse is qualified to get. This particular issue, as elaborated by Alleva (September 2017), can be better understood when all kinds of methods and calculations of the spousal benefits are determined by the SSA.

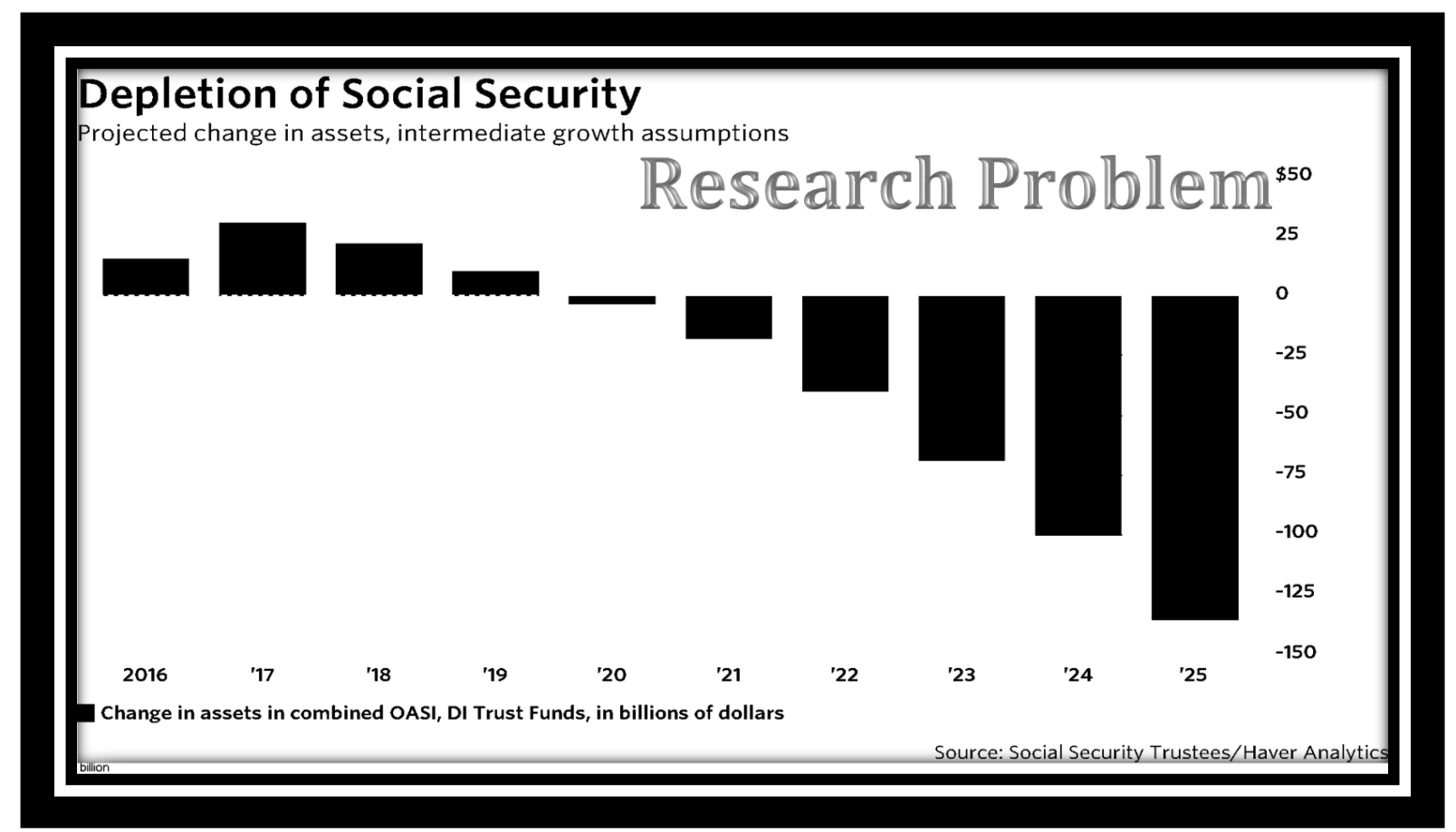

Secondary Source: Market Watch. (July 5, 2017). “Opinion: Social Security Is the Biggest Challenge Facing Us." https://www.marketwatch.com/story/social-security-is-the-biggestchallenge-facing-us-2017-07-05

Figure 1. Change in Assets in Combined OASI, DI Trust Funds, in Billions of Dollars 


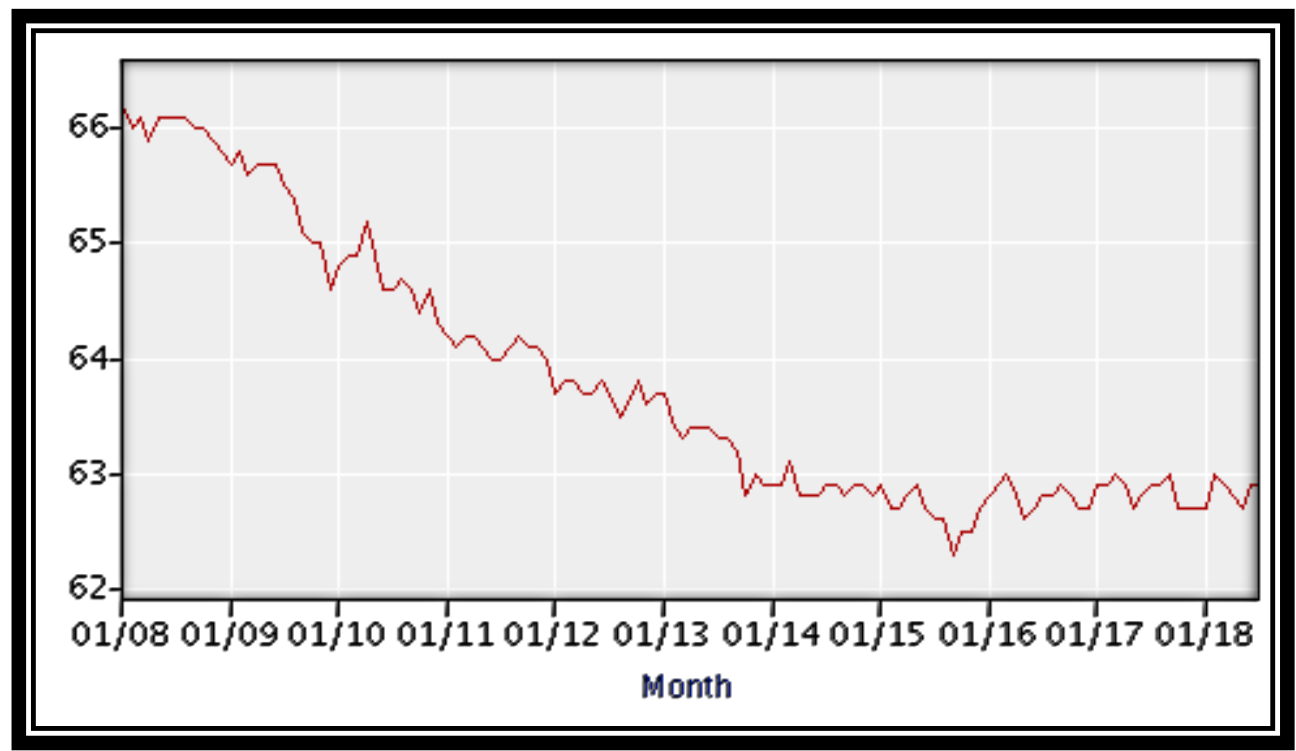

Source: U.S. Bureau of Labor Statistics

Figure 2. U.S. Civilian Labor Force Participation Rate: Seasonally Adjusted, 16 Years \& Older

Since 1935 when it was created, the Old-Age, Survivors, and Disability Insurance program (OASDI), commonly known as Social Security, has provided benefits to retirees and other Americans who would otherwise be unable to work and generate income. The program is funded through mandatory payroll taxes paid by working Americans, and until recently, has worked well to provide these benefits to some of the most vulnerable portions of our population (Applebaum, 2017).

Social Security provides a large percentage of the income of many retired Americans: between 50 and 90 percent, in most cases. Many who are close to retirement have not saved adequately. Without Social Security, it is estimated that more than 40 percent of Americans over 65 would be impoverished. For these reasons alone, it is clear how important Social Security is in keeping retirees safe and healthy (Applebaum, 2017).

Unfortunately, as a large percentage of America's population ages, our Social Security system seems to have also become outdated. As a huge population of Americans known as Baby Boomers have been reaching retirement age, the number of retirees has grown significantly. And as Americans have been having fewer children, the number of people entering the workforce has not been able to keep up with the number of people leaving it. With more and more people retiring and claiming benefits, and less and less people working and paying into the fund, it is expected that the OASDI fund will be depleted before many of us are even close to retirement (Applebaum, 2017).

This research will explore the reasons why the current Social Security system is failing, examine several possible solutions that have been proposed previously, and finally, it will propose a new system that will be more sustainable for the years to come.

In his 2012 article in Generations, Larry J. Polivka (2012) highlighted the dire importance of Social Security benefits in the United States. According to his research, over three-fourths of senior households in our nation are financially vulnerable, and that number is even worse for single senior households. He also found that there is a large gap in the retirement wealth between white and non-white ethnicities, homeowners and renters, and married couples and 
singles. The outlook does not look much better for future retirees, because despite college educations and higher paying jobs, those retiring in the next 30 years will have around the same projected retirement wealth as their parents.

In his book, Social Security: The Unfinished Work, Charles P. Blahous (2010) talks about several causes of Social Security challenges. He says the cost of Social Security is increasing because of the population aging, pay-as-you-go financing, and wage indexing. Population aging provides a burden to Social Security. Pay-as-you-go imposes lower returns on younger generations because as the worker-collector ratio drops, the relationship between taxes collected and benefits paid are no longer proportionate.

Stephen C. Goss (2010) disagrees, and credits the shift in the beneficiary-to-worker ratio almost entirely to the drop in birth rates from over 3 children per woman to around 2 children per woman. According to his research, the increase in life expectancy will not affect age distribution significantly until 2030 or later.

The imminent depletion of Social Security is not new information. The Trust Funds have been paying out more than they're bringing in for nearly a decade, since 2010. In fact, both Republican and Democratic administrations have published annual Trustees Reports including the financial problems being faced by Social Security for more than 30 years in a row (Schobel 2018). So, you may be asking, why hasn't anyone done anything about it yet? In his earlier study, Schobel (July 2017) answers this question: The last major Social Security reform happened in 1983, to avoid trust fund depletion that was scheduled to happen in just a few months. At the time, it was projected that these changes would make Social Security sustainable for 75 years, but changes in assumptions and methods, years later reduced that from 75 years to just 50 . Social Security's income was reduced significantly during the Great Recession, and now the expected trust fund depletion is scheduled to happen between 2029 and 2041.

While the amendments to Social Security added in 1983 were the last significant changes made, several administrations in recent years have tried, and failed, to make further reforms. President George W. Bush made Social Security reform a priority and suggested privatizing a portion of the payroll taxes (Schobel, July 2017). Because this uses flat-rate benefits instead of earningsbased benefits, it takes the interest of low-wage workers into consideration (Grover, 2014).

President Barack Obama also created committees to solve the Social Security problem, and his focus was on maintaining the basic benefit (Grover, 2014). However, it was very difficult for him to get anything done during the last 6 years of his presidency because of the divided nature of the government at that time (Schobel, July 2017).

One of the most popular suggestions to make Social Security sustainable again is to raise taxes. Since 1990, the payroll tax rate has remained the same, so it could be a possibility to raise it. Another solution could be to raise the contribution and benefit base, although this could create the issue of requiring additional benefit credits for those who pay more (Schobel, July 2017). The Congressional Budget Office states that a 4.68 percent increase in payroll tax rate could prevent trust fund depletion (Diamond, 2018). According to Goss (2010), the payroll tax should be raised by about 13 percent to allow Social Security to continue to operate with sustainable solvency for around 75 years. Sustainable solvency means that for the 75-year projection period, not only are the trust funds positive, but the trust fund reserves are either stable or rising (Goss, 2010).

John A. Turner (2016) acknowledges that raising tax revenue could restore solvency, but warns that this idea would not be popular. Another contemporary solution, according to Diamond 
(2018), proposed in the Social Security Subcommittee of Ways and Means, may prove to be a bit more popular. It heavily increases both the tax rates and the tax base, but also increases benefits. This proposal would raise revenue very quickly, much more quickly than it would raise costs.

Another popular proposed solution is to cut benefits. Again, this idea would not be a popular one. One of the most important themes of Social Security is to ensure the retirees' life quality, thus, cutting benefits needs to be considered precisely (Turner, 2016). There are two ways to cut benefits, which are raising the retirement age and reducing the generosity of the benefit formula. Turner stated that when the normal retirement age reaches 67 , early retirement benefits will be cut from 80 percent of the primary insurance amount to 70 percent. The early retirement age in United States is 62. Reasonably raising it could be necessary, according to Turner, since it is widely accepted. He indicates that in other countries such as the United Kingdom, Switzerland, New Zealand, and Ireland, the retirement age is older than the United States'. However, it needs also consider the interest of lower income people since most of their income after retirement comes from Social Security (Turner, 2016). For this reason, Schobel (July 2017) does not believe that raising the retirement age would work now, although it has been used in the past (Schobel, July 2017).

The article Social Security Automatic Adjustment written by Bruce D. Schobel in March 2017 talks about the benefit formula. Low paid workers can take advantage of the weighted benefit formula. "Regarding the PIA formula, benefits are based on 90 percent of average indexed monthly earnings (over the best 35 years) up to the first bend point, plus 32 percent up to the second bend point, plus 15 percent of any average indexed monthly earnings exceeding the second bend point" (Schobel, March 2017, p. 54).

If the worker-collector ratio drops, the burdens will be bigger. One possible way to control this burden is to decrease the benefit accordingly and simultaneously. To figure out the levels of cutting benefits, we first need to know how Social Security distributes benefits. It's mainly based on benefit formulas with several considerations involved, such as wage income level, longevity, marital status and birth year (Blahous, 2010). According to Goss (2010), a benefit reduction of about 13 percent would restore sustainable solvency.

Schobel (July 2017) suggests reducing the growth in benefits by implementing a chained CPI, which was actually included in one of Obama's budgets but never enacted. Overall, he notes that it isn't likely that benefits that are currently being paid will be reduced. It is much more likely that benefits to be paid in the future, to younger people who already have low expectations about their Social Security benefits, will be reduced (Schobel, July 2017). A different proposal, by the Chairman of Social Security Subcommittee of Ways and Means, suggests benefit cuts, except for those of low earners, and zero change in payroll tax rate or payroll tax base. This plan would lower revenue somewhat and then cause a sharp drop in costs (Diamond, 2018).

Alternatively, Polivka (2012) suggests that because of the dependence of so many Americans on Social Security, Social Security benefits, especially for those beneficiaries with low income, should be increased. He also suggests more opportunities for employment for older workers, as well as more openly available information regarding retirement accounts. Unfortunately, no suggestion is given on how to pay for the increase in benefits.

The third main solution that is usually proposed involves privatization. This is a type of paradigmatic reform, which changes the fundamental structure: for example, introducing individual accounts (Turner, 2016). Full privatization means that individuals can take all the 
assets in their own pocket. This also increases the saving rate and boosts the economy. Privatization involves plenty of risks, but working close with the professional financial management team and using various investment strategies provided by them can effectively minimize the risk (Koleva, 2012).

In a real-life example, Chile changed the system to full privatization. At first, the results were positive since it provided higher returns on investment. Later on, they found that varied market conditions, low participation rates, and high government costs were some major issues with this system. Therefore, full privatization is not an effective solution for the long term. Koleva (2012) indicates that Social Security is to fulfill the most basic needs to low wage workers, however, high wage workers can choose the private retirement accounts as a supplement. This kind of partial privatization would be more effective (Koleva, 2012). As previously mentioned, this idea was suggested by George W. Bush in recent years. However, because this was argued to cause the trust funds to be depleted more quickly, it did not move forward very far (Schobel, July 2017).

Stephen C. Goss (2010) made it clear that we needed to act sooner rather than later when it comes to Social Security reform. Much greater benefit cuts and tax increases will need to happen if we wait until the trust funds are completely exhausted (Goss, 2010). Because Congress and the president have been not yet been able to come up with a solution to restore balance to Social Security, we may be missing opportunities to use some of the solutions we have available to us. For example, in 1983, when the retirement age was raised from 65 to 67, it had no effect until 17 years later due to the grace period they allotted. If we wait much longer to make the necessary changes, we will not have enough time (Schobel, 2018). Passing a bill now, while there is a Republican president and a Republican majority in Congress, is a real possibility (Schobel, July 2017).

Overall, the causes of the fall of Social Security vary, but the solutions fall into mainly three categories: partial privatization, increasing tax revenue and cutting benefits. Regardless of which option is chosen, putting it into practice and achieving the expected results will take time. For that reason, the U.S. Congress needs to move quickly to make a decision and begin the implementation process.

\section{THE METHODOLOGY}

\section{Risk Analysis and Social Security Investment}

Social Security's main purpose has been a secured supplemental retirement source of income for millions of citizens. Hence, some understandably risk-averse attitudes have prevailed for years in funds management. That is a highly preferred approach for most individuals, should they ever be in charge of investing their accumulated premiums paid for years by both their employers and themselves. However, given other devastating risks being increasingly encountered by this nation, i.e., an expected insolvency of Social Security Trust Fund, various involving risks must be more skillfully managed in some available innovative ways that have been facilitated and explored through modern financial technology, introduced and practiced by financial innovators.

Comparison: Key Measures of Actuarial Status in the Social Security Trustees Reports 


\begin{tabular}{|c|c|c|}
\hline 75-year actuarial deficit & 2017 Report & 2018 Report \\
\hline As a percentage of taxable payroll $2.83 \% 2.84 \%$ & $2.83 \%$ & $2.84 \%$ \\
\hline As a percentage of GDP $1.0 \% 1.0 \%$ & $1.00 \%$ & $1.00 \%$ \\
\hline \multicolumn{3}{|l|}{ Income and outgo in year prior to report year (in billions) } \\
\hline \multicolumn{3}{|l|}{ Income } \\
\hline Total & $\$ 957$ & $\$ 997$ \\
\hline Social Security contributions ${ }^{a}$ & $\$ 836$ & $\$ 874$ \\
\hline Income taxes on benefits & $\$ 33$ & $\$ 38$ \\
\hline Interest & $\$ 88$ & $\$ 85$ \\
\hline \multicolumn{3}{|l|}{ Outgo } \\
\hline Total & $\$ 992$ & $\$ 952$ \\
\hline Benefit payments ${ }^{b}$ & $\$ 916$ & $\$ 946$ \\
\hline Administration & $\$ 6$ & $\$ 6$ \\
\hline Net increase in assets & $\$ 35$ & $\$ 44$ \\
\hline \multicolumn{3}{|l|}{ Trust fund reserves } \\
\hline Amount at beginning of report year (in billions) & $\$ 2,848$ & $\$ 2,892$ \\
\hline Amount at beginning of report year (as a percentage of report year outgo) & $298 \%$ & $288 \%$ \\
\hline Year of peak trust fund reserves & 2,021 & 2,017 \\
\hline Amount at end of peak year (in billions) & $\$ 3,000$ & $\$ 2,892$ \\
\hline \multicolumn{3}{|l|}{ Year of trust fund depletion } \\
\hline OASDI & 2,034 & 2,034 \\
\hline OASI & 2,035 & 2,034 \\
\hline DI & 2,028 & 2,032 \\
\hline \multicolumn{3}{|l|}{ Share of OASDI outgo covered by scheduled revenue in- } \\
\hline Year of trust fund depletion & $77 \%$ & $79 \%$ \\
\hline End of 75-year reporting period & $73 \%$ & $74 \%$ \\
\hline
\end{tabular}

SOURCE: 2017 and 2018 Trustees Reports, June 2018

${ }^{a}$ Includes a small amount of reimbursements from the General Fund of the Treasury due to the payroll contribution holiday.

b Includes a small amount of payments to the Railroad Retirement Board.

${ }^{c}$ Measured at end of year.

\section{Some Innovative Portfolio Management Approaches}

Considering the retirement nature of social security investment, it has always been viewed too risky for SSA and the nation to tap on to investment funds with higher returns. However, like anything else, when limitations grow critically, assuming some managed risk, hedged by some insurance choices, one could enhance rates of return to much higher levels as an alternative to raising social security premiums by law. The authors are recommending a list of the following options that could be partially or massively adopted, when needed:

1. SSA could seek some solid insurance policies similar to ERISA (Employment Retirement Income Security Act, 1974) through federal government legislation, as discussed by Miller \& VanHoose (2007). 
2. Given a solid insurance coverage, supporting social security trust funds, SSA can adopt an appropriate set of financial engineering actions in which the rates of return could be increased to much higher levels.

3. Consider the rather recent and modern choices, such as corporate banking solutions for longer-term investment of funds, which are often less secured but can be secured by an insurance coverage, as mentioned above. The corporate banking available services (Hamzaee, 2014) and products include a broad list, such as the following.

Table 1: Some Examples of Popular Investment Instruments

\begin{tabular}{|c|c|c|c|c|}
\hline \% CHANGE & Y-T-D & 1-YR CHG & 5-YR AVG & 10-YR AVG \\
\hline DJIA & 4.33 & 18.39 & 14.36 & 12.65 \\
\hline NASDAQ & 15.10 & 26.70 & 23.45 & 23.59 \\
\hline S\&P 500 & 7.52 & 17.86 & 14.56 & 12.69 \\
\hline REAL YIELD & $8 / 24$ RATE & 1 YR AGO & 5 YRS AGO & 10 YRS AGO \\
\hline 10 YR TIPS & 0.73 & 0.44 & 0.69 & 1.64 \\
\hline
\end{tabular}

Sources: Duane Roth, "Weekly Economic Update," 08/ 27/2018 \& wsj.com, bigcharts.com, treasury.gov $-8 / 24 / 18$

Indices are unmanaged, do not incur fees or expenses, and cannot be invested into directly. These returns do not include dividends. 10-year TIPS real yield = projected return at maturity given expected inflation.

- Asset Finance (Leasing)

- Business Capital

- Capital Markets

- Cash Management

- Commercial Real Estate

- Global Trade Finance

- Lending

- Merchant Services

- Risk Management

- Wealth Management

- Winning the Competition

- Software Development to Make It Convenient (make an unavoidable package)

4. The innovative investment options of the modern time have opened doors for new approaches to financial investment, such as a conservative bundle of portfolio investment, in which a life insurance and a pension accumulation can be structured in a way that a regular payment would secure a life insurance policy, exempt from taxation. Meanwhile funds invested would add up to an annuity, which would make a set of lifetime tax-exempt monthly payment for investors after a certain period of time.

5. It would be more appropriate to let higher-income individuals take control of a fraction of their accumulated social security benefits and invest through some certified financial agents, while continuing to require others with low retirement incomes to depend entirely on the Social Security Administration's fund management.

6. Crediting the Social Security Trust Funds annually by the federal government with its collected federal taxes on social security benefits. This would be a well-deserved fund accumulation every year. 
7. The unnecessary huge tax reductions for the super-rich individuals and corporations could be moderated and some fraction, such as 5 percent, of the tax drops could be easily boosting the Trust Funds' reserves every year.

8. Social Security premiums eventually need to be formulated into a progressive rates for a more equitable income distribution.

9. Trust Fund's net reserves and income would be boosted partially by designating Social Security Administration's employees and personnel as federal government's employees, and paid from the same federal government sources not the beneficiaries' premium payments.

10. At the end of each fiscal year, all 12 district Federal Reserve Banks are supposed to provide all the surpluses of their annual incomes over their expenses to the federal government. Given the heavily significance of the social security for millions of Americans, those surpluses could also be rechanneled to the Social Security Trust Fund, where the need is more essential for the security of the U.S. labor force.

11. The Social Security Trust Fund is legally the U.S. federal government's obligation to program beneficiaries. Yet, it is ironic that the U.S. government had borrowed more than $\$ 2.3$ trillion by several U.S. administrations, including Presidents Reagan, Bush, etc., from the Trust Fund and used the money for purposes other than the legallydesignated social security plans. The U.S. Congress must require the federal government to pay high interest rates on those improperly borrowed funds, which would hopefully and partially contribute to the Trust Fund's solvency.

\section{THEORETICAL FRAMEWORK \& ANALYSES}

Theoretically one can apply several approaches, based on risk, rate of return, risk-attitudes and preferences, Social Security Trust Fund's Budget for investment and expenses, based on several facts encountered by this nation, including the main three, as listed below:

Fact No. 1: Trust Fund's total income has been diminishing, as shown in Figure 3 by the authors' nonlinear (quadratic) trend estimation.

Fact No. 2: Social Security Expenditures have been growing, and are realistically expected to be growing even further, as obviated in the authors' linear trend analysis, presented in Figure 4.

Fact No. 3: Trust Fund has been losing net income, both types of trend analysis would confirm that in Figure 5 (linear trend) and Figure 6 (nonlinear trend). 


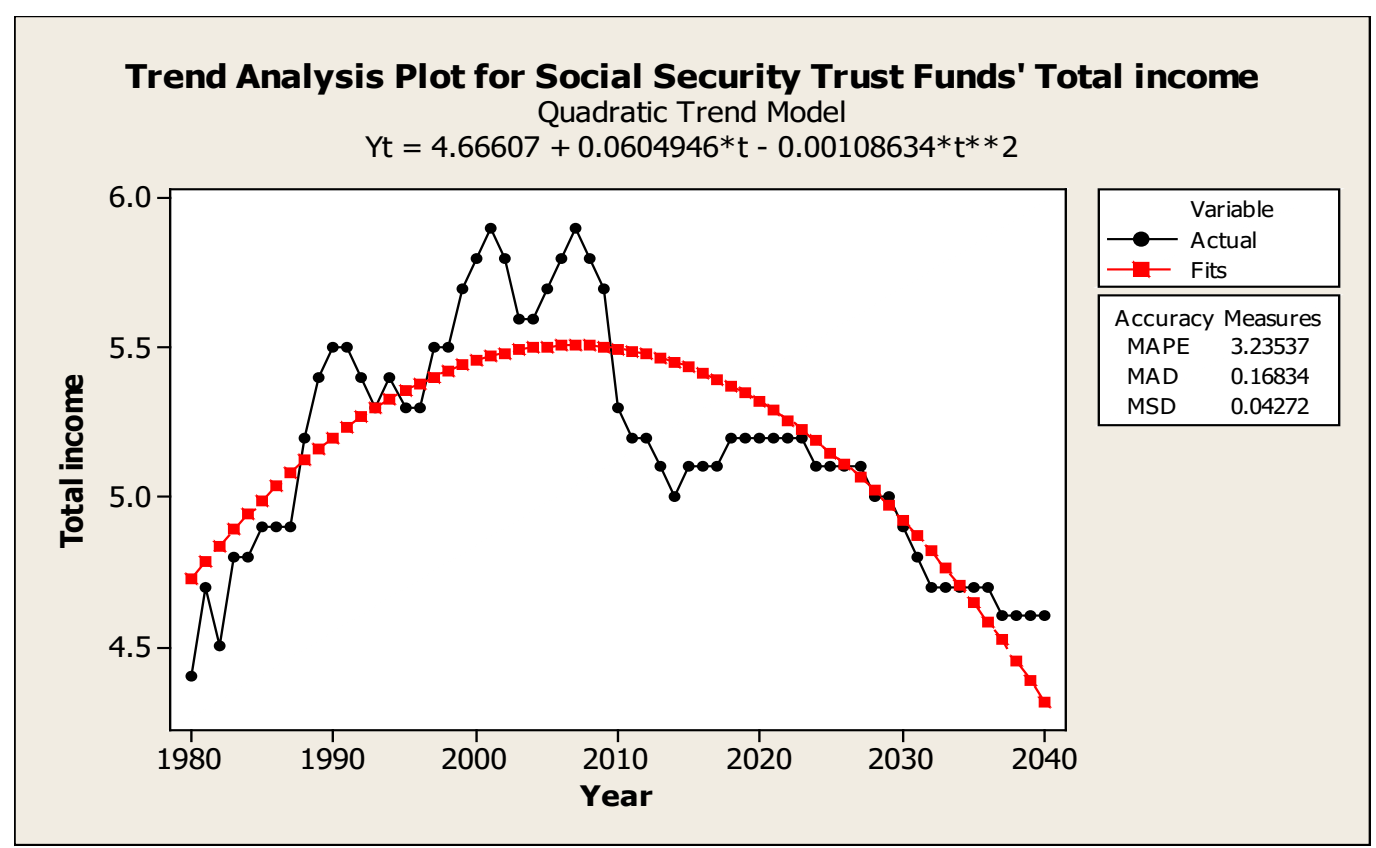

Source of Data: SSA (2013, Table 4.A1) and Board of Trustees (2014)

Figure 3. Quadratic Trend Analysis: Estimated by the Authors

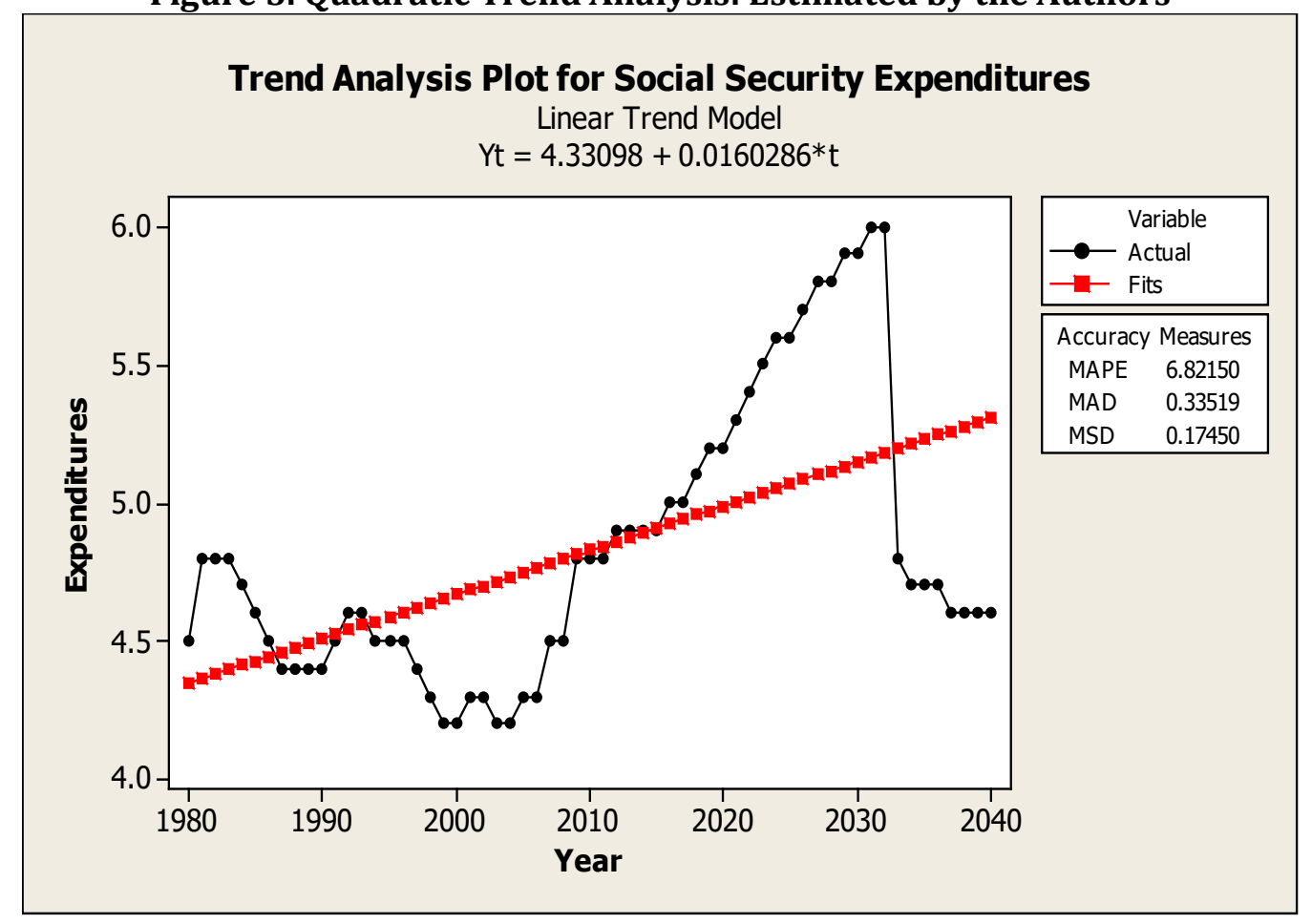


Source of Data: SSA (2013, Table 4.A1) and Board of Trustees (2014)

Figure 4. Linear (Optimal) Trend Analysis: Estimated by the Authors

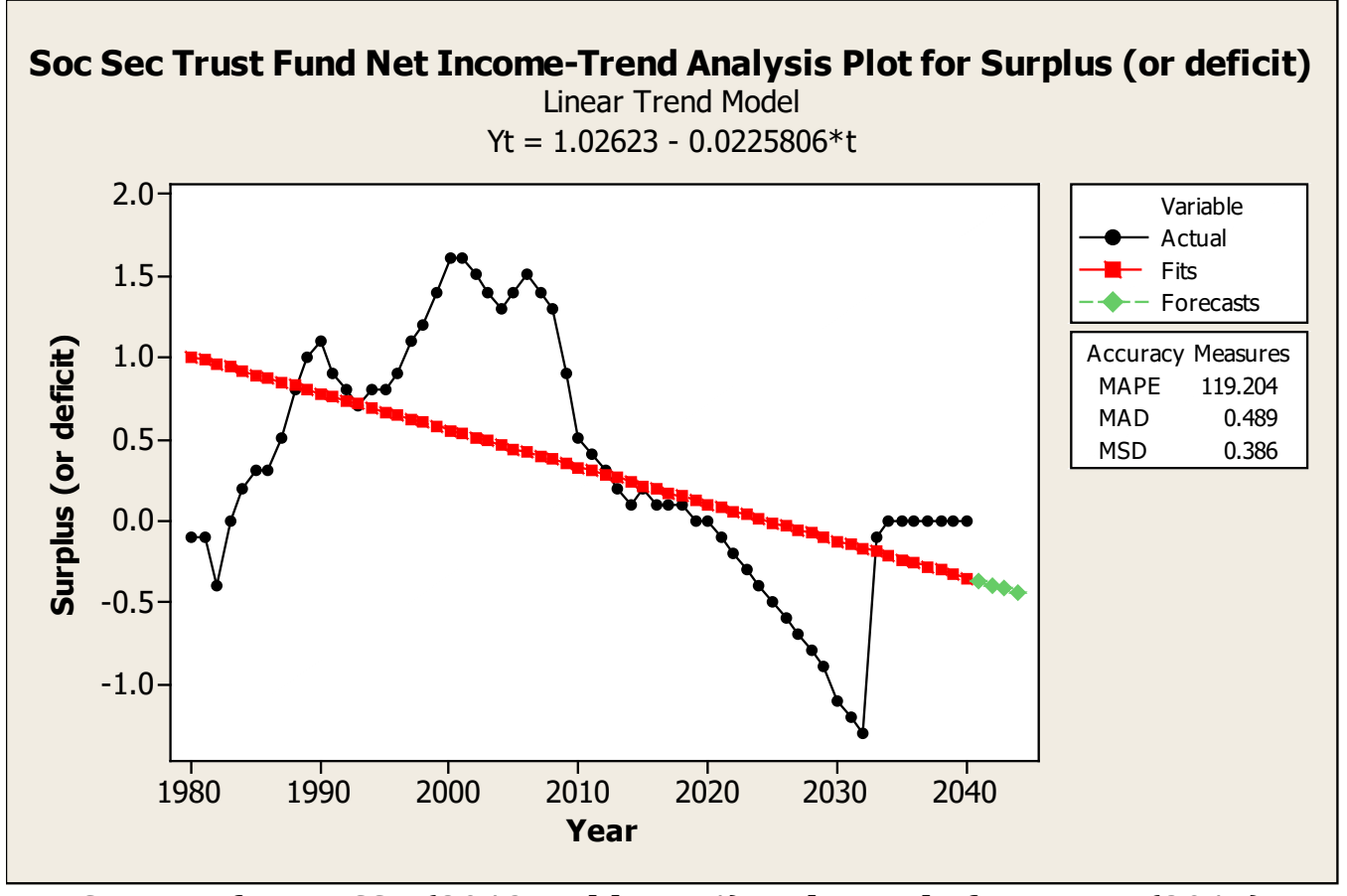

Source of Data: SSA (2013, Table 4.A1) and Board of Trustees (2014)

Figure 5. Linear (Optimal) and Nonlinear (Quadratic) Trend Analysis: Estimated by the Authors

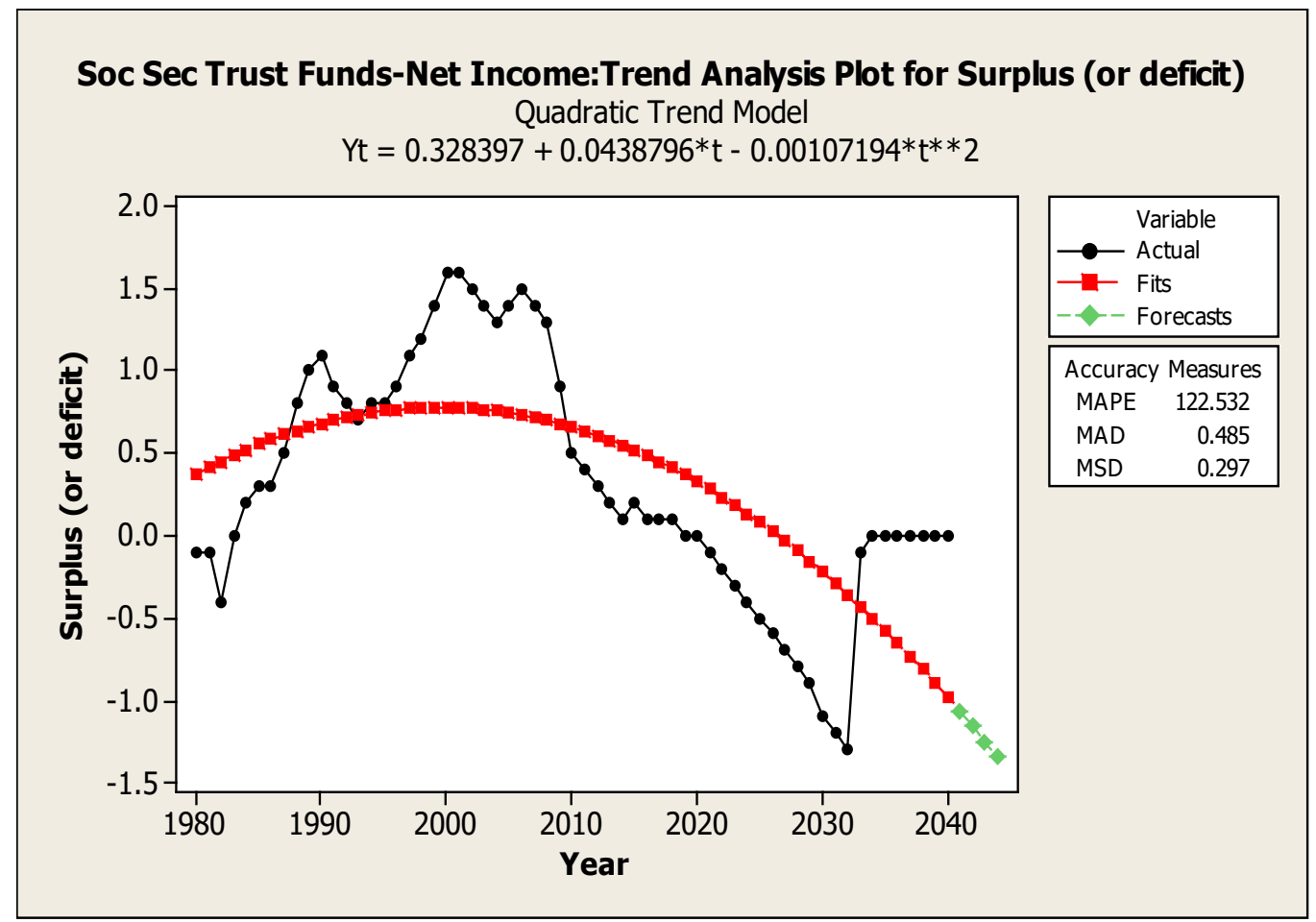


Source of Data: SSA (2013, Table 4.A1) and Board of Trustees (2014)

Figure 6. Nonlinear (Quadratic) Trend Analysis: Estimated by the Authors

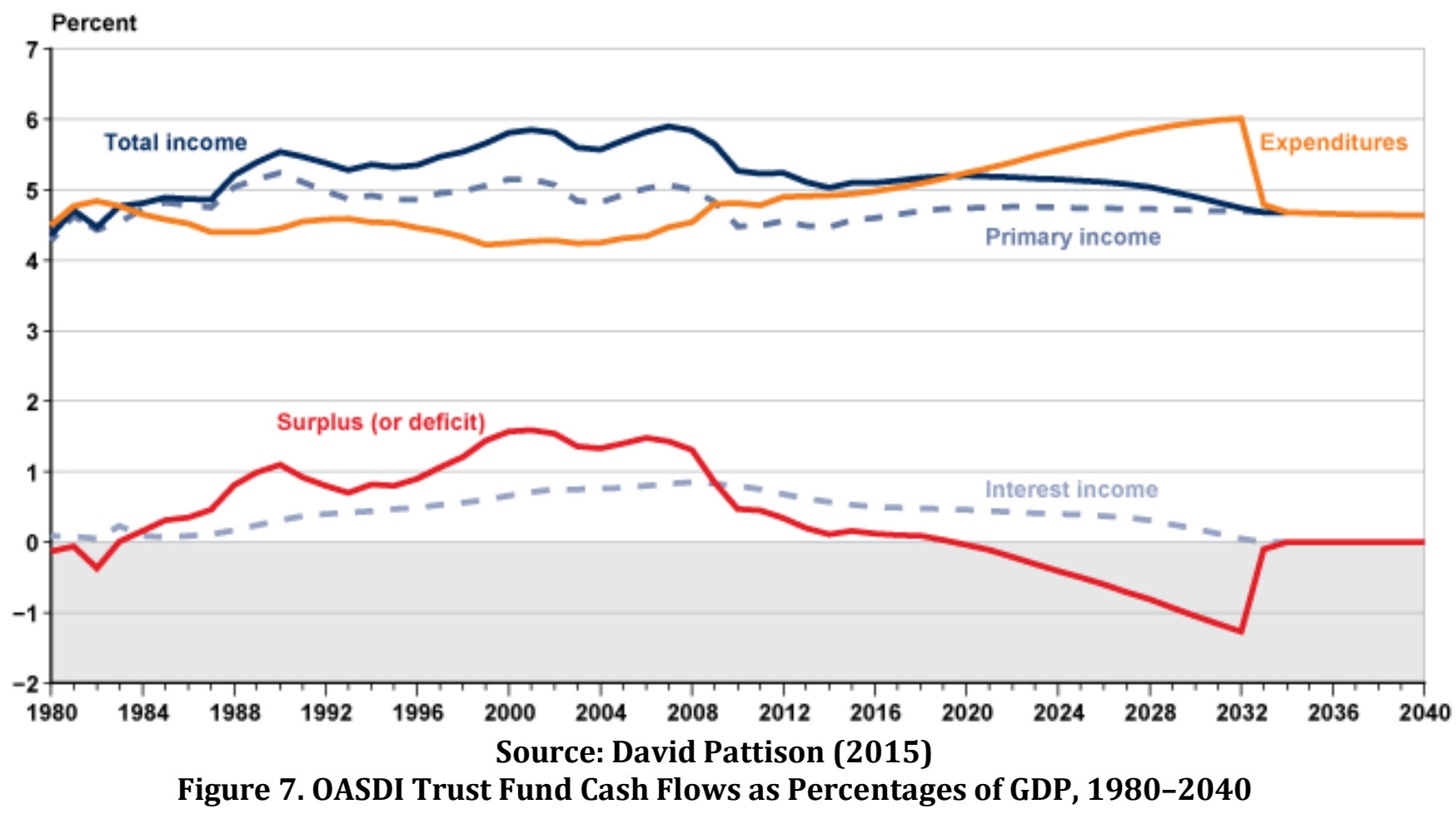

Based on those facts, the following theoretical framework is presented with a focal target on making an objective function for maximization of Trust Fund's expected net earnings (NEE), while risks, rates of return, and probabilities are incorporated in the model. The objective model would include a grand total expected rate of return on all $\mathrm{j}$ groups of invested assets, each containing i various individual assets, where $i=1,2, \ldots, n$ various individual assets, and $j=1,2, \ldots$, $m$ different groups of assets.

$E R R_{j k}=p_{j k} R R_{j k}$

$E R R_{j k}=$ Expected rate of return on the kth asset, within assets group of $j$

$j=1,2, \ldots, m$ groups of assets

$k=1,2, \ldots, n$ different assets in each of $m$ groups

$R R_{j k}=$ Rate of return on the $k$ th asset, within assets group of $j$

$p_{j k}=$ The probability of the rate of return on the kth asset to be $R R_{j k}$

Or expressing (1) differently:

$E R R_{a}=p_{a 1} R R_{a 1}+p_{a 2} R R_{a 2}+\ldots+p_{a k} R R_{a k}$
$E R R_{b}=p_{b} R R_{b 1}+p_{b 2} R R_{b 2}+\ldots+p_{b 1} R R_{b k}$

$E R R_{b}=p_{b 1} R R_{b 1}+p_{b 2} R R_{b 2}+\ldots+p_{b k} R R_{b k}$

$E R R_{j}=p_{j 1} R R_{j 1}+p_{j 2} R R_{j 2}+\ldots+p_{j k} R R_{j k}$ 


\section{where:}

$j=1,2, \ldots, m$ groups of assets

$k=1,2, \ldots, n$ different assets in each of $m$ groups

$R R_{j k}=$ Rate of return on the kth asset, within assets group of $j$

$p_{j k}=$ probability of $R R_{j k}$ to be realized

So the total ERR for Social Security Trust Fund in period $t$ on all the $\mathrm{n}$ invested assets of all the $m$ groups of assets will be summarized in the following equation:

$$
E R R_{t}=\sum_{j=1}^{m} \sum_{k=1}^{n} E R R_{j k t}=\sum_{j=1}^{m} \sum_{k=1}^{n} p_{j k} R R_{j k t}
$$

Applying linear programming techniques, each of the 5 hypothetical lines in Figure 1 represents a particular trade-off between expected investment security $\left(\mathrm{S}_{\mathrm{ij}}=\left(1 / \beta_{\mathrm{ij}}\right)\right.$, and $E R R_{i j}$ or expected rate of return for one (ith) adopted asset within aj-th group of assets, or one (jth) adopted group of assets, containing $\mathrm{n}$ various assets:

$$
\begin{aligned}
& S_{i j}+\theta_{i j} p_{i j} R R_{i j}=v_{i j} \\
& S_{i j}=v_{i j}-\theta_{i j} p_{i j} R R_{i j} \\
& S_{i m}=v_{i m}-\sum_{i=1}^{n} \theta_{i m} p_{i m} R R_{i m} \\
& S_{i m}=v_{i m}-\theta_{i m} E R R_{i m} \\
& p_{i m}=\frac{R R_{i m}}{T}
\end{aligned}
$$

$\theta_{i j}=\frac{\Delta \beta_{i j}}{\Delta E R R_{i j}}$

where, $p_{i m}$ is a $T$ - year average rate of return on the $m$ - th group of $i$ vrious assets and $T=e . g ., 5$ or 10 years. Hence, $p_{i m}$ can be also considered as a proxy for the probability of a rate of return, $R R_{\text {im }}$ to be realized on asset $i$ of the group (or class) $m$. And also, 
$S_{i j}=\frac{1}{\beta_{i j}}=$ Expected $\sec$ urity of investment in the ith asset of the jth group of assets, or $v_{i j}$ $v_{i,}=$ an empirically - determined constant $R R_{i j}=$ Rate of return on the ith asset, within assets group of $j$ th $p_{i j}=$ The probability of the rate of return on the ith asset within the jth group to be $R R_{i j}$ $\theta_{i j}=\frac{\Delta S_{i j}}{\Delta E R R_{i j}}=$ Attitudes towards sec urity $=$ Extra amount of security willing to exchange for every additional unit of expected rate of return 
$\left(\mathrm{S}_{\mathrm{ij}}=\left(1 / \beta_{\mathrm{ij}}\right)\right.$

Expected Security

on, e.g., 5 Various

Assets

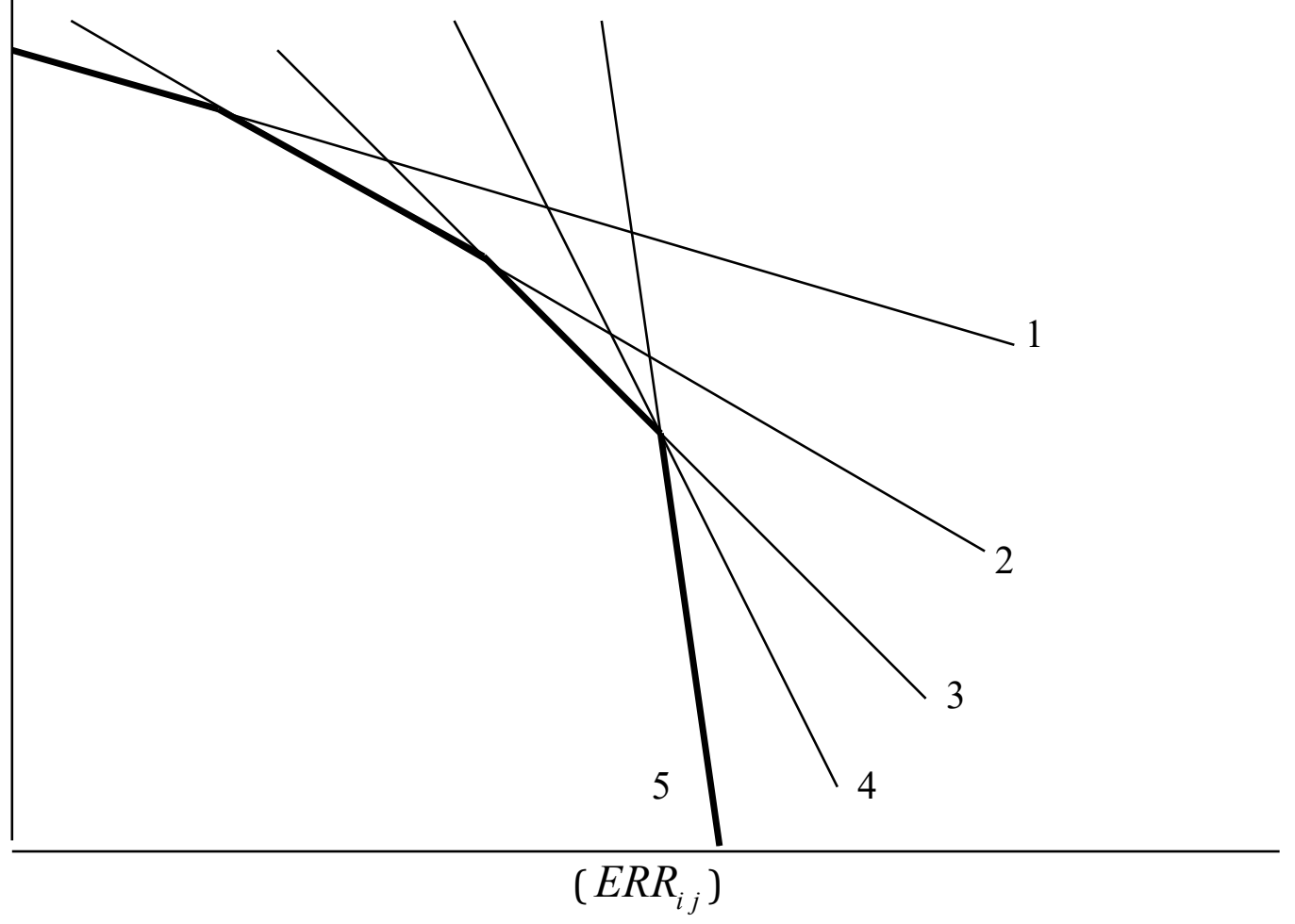

Expected Rate of Return on, e.g., 5 Various Assets

Figure 8. An Integrated Asset Portfolio Held by Social Security Administration Production

Possibilities Curve (two outputs of expected security and expected rate of return)

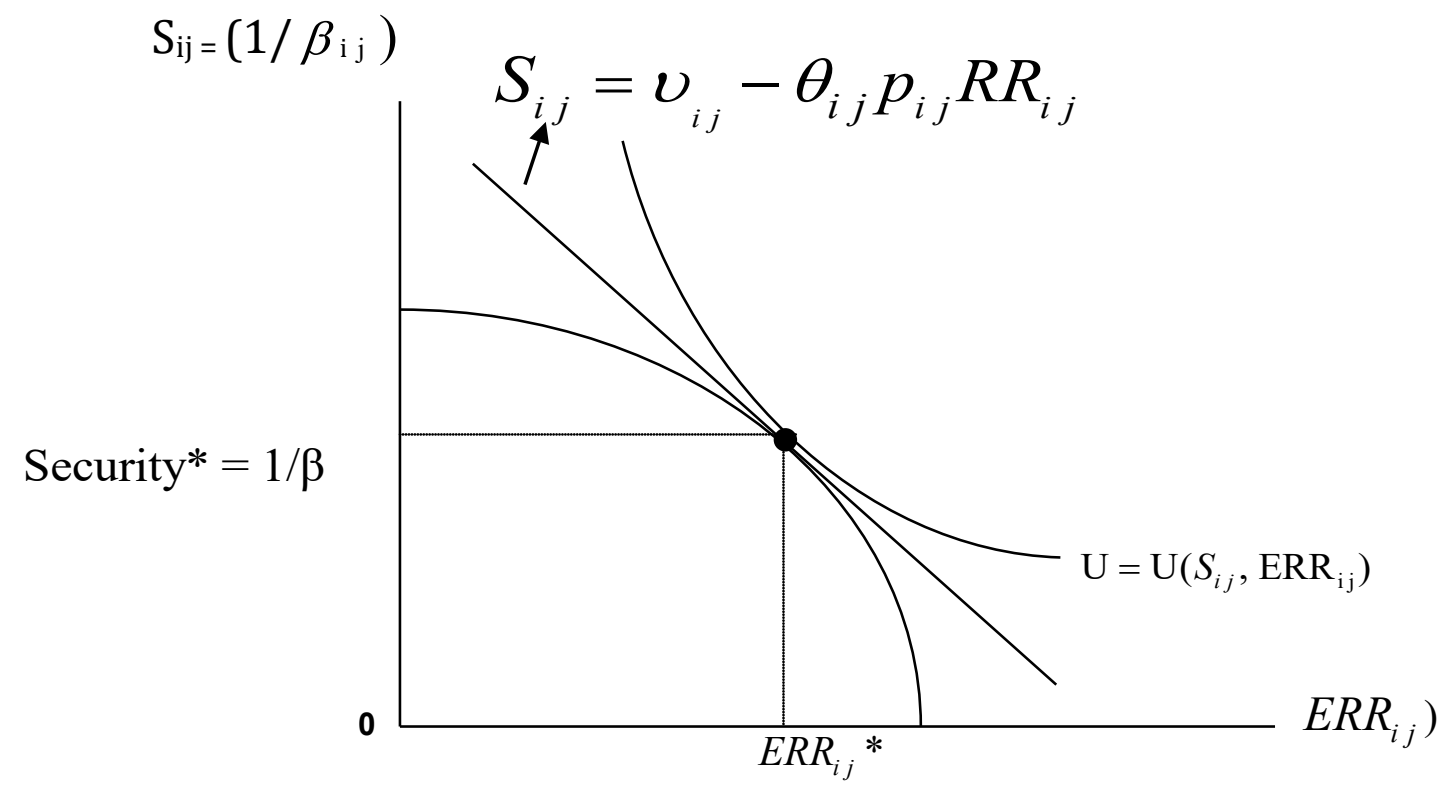


Figure 9. Trust Fund's PPC, Beneficiaries' Preference Function \& the Collective Budget Constraint: Assuming Smooth $U$ and PPC Functions

In Figure 9, the optimal levels of risk and expected rate of return for both Trust Fund (denoted by "TF") and the beneficiaries or individuals (denoted by "Ind") coincide. However, with various tastes (utility) for risk versus expected rate of return, as depicted in Figures 10 and 11, given the same collective budget constrain (the linear function), the individual beneficiaries' choices will differ from those of Trust Fund administrators, who perform their portfolio management on behalf of the beneficiaries.

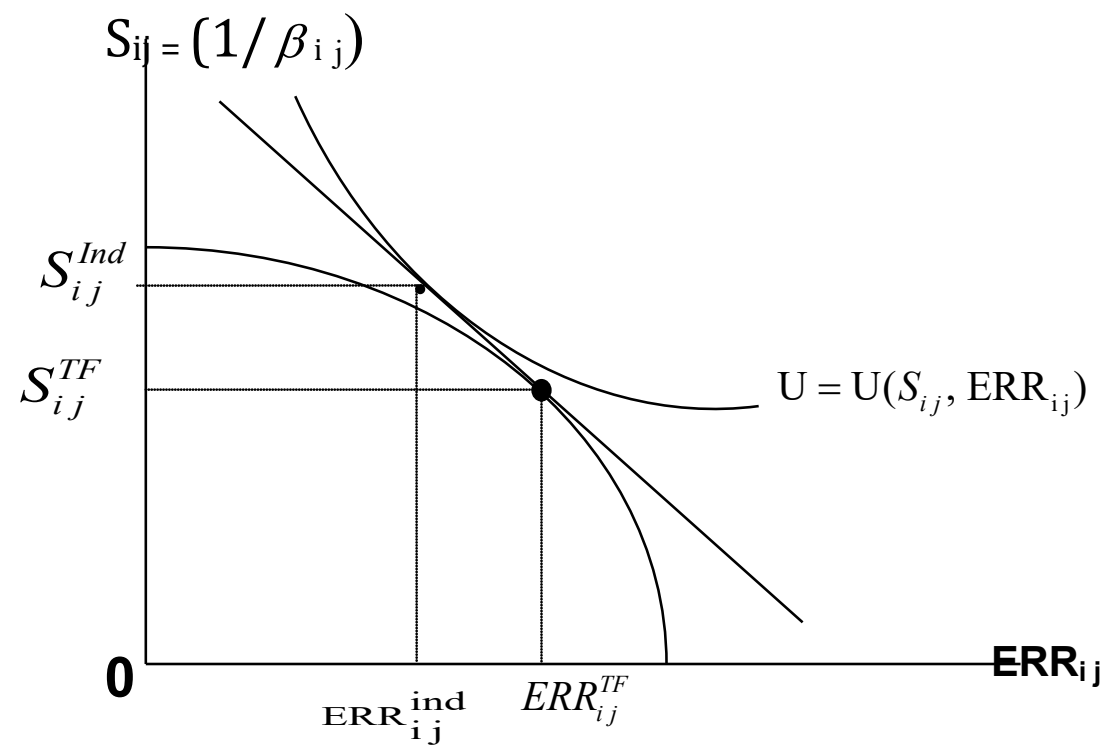

Figure 10. Second Outcome: Different Optimal Choices of Security versus Expected Rate of Return for Trust Fund Management and the Individuals (or Beneficiaries)

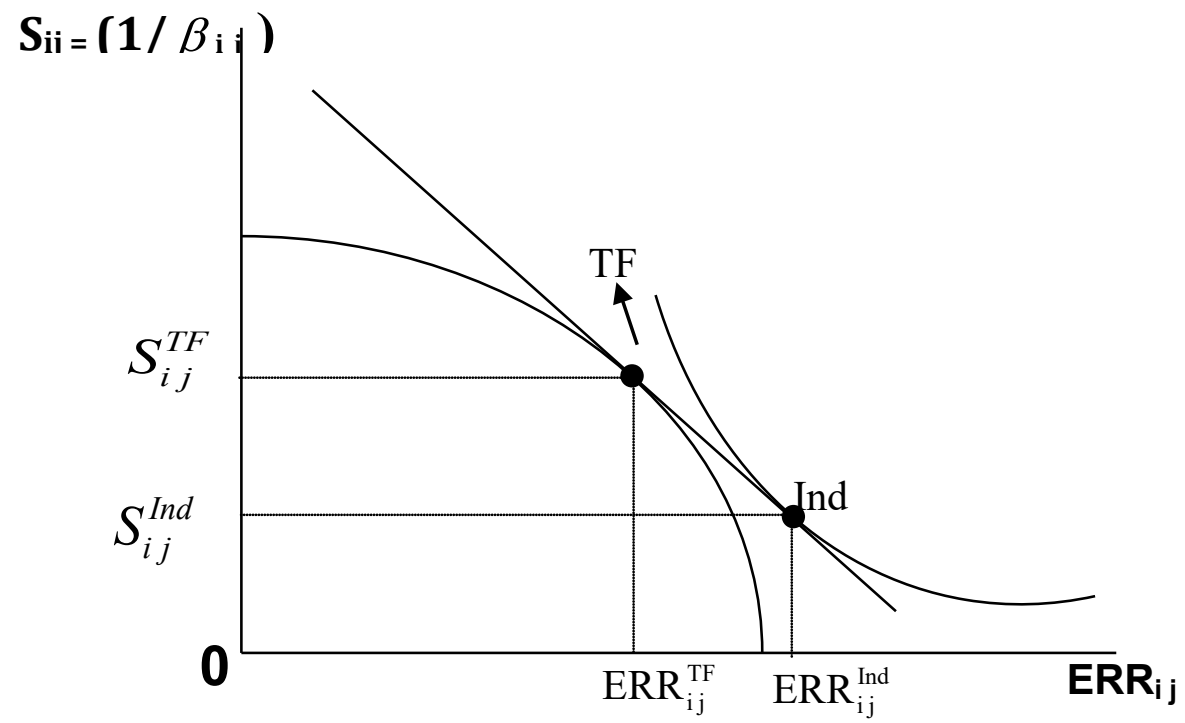

Figure 11. Third Outcome: Different Optimal Choices of Security versus Expected Rate of Return for Trust Fund Management and the Individuals (Beneficiaries)

\section{SUMMARY AND CONCLUSION}

This research has provided a critical review of the Social Security system, as is, a review of the major innovative policy and/or funds management resolutions, and finally presented a new approach conducive to the Social Security Trust Fund's more dynamic growth and adequacy as well as some project-management-based policy prescriptions for its sustainability. 
In terms of portfolio management and optimization techniques, a set of equations are formulated originally by the authors that would provide a tradeoff between expected rate of return and security index (opposite to risk index) through several possible financial instruments, such as bonds, mutual funds, S\&P 500 Index, fixed index annuities, etc. In that collective approach, linear programming procedure is presented to build the production possibilities frontier, given the Trust Fund's reserves, and all other constrained resources. Based on the Trust Fund's preferences, reflecting those of the beneficiaries, the optimization decisions would be more reliably determined.

Finally, the strategic success of the Trust Fund's portfolio management would necessitate some elements of risk to enjoy higher rates of return available in these financial innovations and modernity. On the other hand, establishing some federally operated and sponsored insurance opportunities for the Trust Fund, would make it both safer and more profitable at the same time. Given the historical date on rates of return, risk coefficients, and security index for various instruments, our model could be applied both graphically and mathematically.

\section{References}

Alleva, Brian J. (September 2017). "Social Security Retirement Benefit Claiming-Age Combinations Available to Married Couples." Research and Statistics Note. 2017-01.

Alleva, Brian J. 2015. "Minimizing the Risk of Opportunity Loss in the Social Security Claiming Decision." Journal of Retirement, 3(1), 67-86.

Census Bureau. 2017. "America's Families and Living Arrangements: 2016."

https://www.census.gov/data/tables/2016/demo/families/cps-2016.html.

Blahous, C. (2010). "Social Security: The Unfinished Work." Stanford, Calif.: Hoover Press.

Collins, J. M. and C. Urban. (2015). "The Role of Information on Retirement Planning: Evidence from a Field Study." Working Paper.

Diamond, P. (2018). "The Future of Social Security." Economic Inquiry, 56(2), 661-681.

Goss, S. (2010). "The Future Financial Status of the Social Security Program." Social Security Bulletin, 70(3), 111125.

Grover, T. (2014). Social Security Reform: Current Issues and Legislation. Nova Science Publishers, Inc.

Hamzaee, Reza G. and Wold, Samuel. (2014). "Evolving Strategies of Corporate and Private Banking.” Global Business and Economics Anthology.

Koleva, Y. (2012). "The Outlook for Social Security Reform: Proposal and Implications." Journal of Financial Service Professionals, 66(3), 26-31.

Lusardi, A. and O. S. Mitchell. 2007. "Financial Literacy and Retirement Preparedness: Evidence and Implications for Financial Education." Business Economics, 35-44.

Market Watch. (July 5, 2017). "Opinion: Social Security Is the Biggest Challenge Facing Us." https://www.marketwatch.com/story/social-security-is-the-biggest-challenge-facing-us-2017-07-05

Miller, Roger LeRoy and VanHoose, David D. (2007). Money, Banking \& Financial Markets. Thomson - South Western. Third Edition: 174-175.

Munnell, A., M. S. Rutledge, and A. Webb. (2014). "Are Retirees Falling Short? Reconciling the Conflicting Evidence." Working paper 2014-16. Chestnut Hill MA: Center for Retirement Research at Boston College.

Office of Retirement and Disability Policy. (June 2018). "Summary: Actuarial Status of the Social Security Trust Funds." www.ssa.gov/policy

Pattiston, David. (2015). "Social Security Trust Fund Cash Flows and Reserves." Social Security Bulletin, 75 (1).

Polivka, L. (2012). “A Future Out of Reach? The Growing Risk in the U.S. Retirement Security System." Generations: 36(2), 12-17. 
Puckett, Carolyn. (2010). “Administering Social Security: Challenges Yesterday and Today.” Social Security Bulletin, 70 (3). https://www.ssa.gov/policy/docs/ssb/v70n3/v70n3p27.html

Sarney, Mark A. (December 2017). “A Field Guide to Social Security Distributional Analysis.” No. 2017-02. Research, Statistics, \& Policy Analysis, Social Security Administration.

https://www.ssa.gov/policy/docs/rsnotes/index.html

Schobel, B. (July 2017). “Are Major Social Security Changes Coming Soon?” Journal of Financial Service Professionals, 71(4), 44-48.

Schobel, B. (March 2017). "Social Security's Automatic Adjustments." Journal of Financial Service Professionals, 71(2), 50-54.

Schobel, B. (2018). “Social Security Risks.” Journal of Financial Service Professionals, 72(4), 35-38.

Scholz, J. K., A., Seshadri, and S. Khitatrakun. 2006. “Are Americans Saving Optimally for Retirement?” Journal of Political Economy, 114(4), 607-643.

Turner, J. (2017). Sustaining Social Security in an Era of Population Aging. Kalamazoo, MI: W.E. Upjohn Institute.

Williams, Sean. (Aug 27, 2016). "The 4 Biggest Problems Facing Social Security.” The Motley Fool.

https://www.fool.com/retirement/2016/08/27/the-4-biggest-problems-facing-social-security.aspx 